\title{
FOLIICOLOUS LICHEN COLLECTIONS ON MOUNT KANGA, TANZANIA (EAST AFRICA)
}

\author{
E. FARKAS \\ Institute of Ecology and Botany, Centre for Ecological Research \\ Hungarian Academy of Sciences, H-2163 Vácrátót, Alkotmány u. 2-4, Hungary \\ E-mail:farkas.edit@okologia.mta.hu
}

(Received 15 June, 2014; Accepted 30 November, 2014)

\begin{abstract}
The Tanzanian Mt Kanga was at first visited by Tamás Pócs in 1987 when he collected foliicolous lichens in lowland rainforest between 800 and $900 \mathrm{~m}$ elevation and in submontane rainforest between 900 and 1,250 m. Later, in 1989 he returned there with participants of the Nguru Mts expedition, when the author collected further lichens including foliicolous ones in three different forest types (dry evergreen and semi-evergreen forest at 600-800 $\mathrm{m}$, submontane rainforest at 850-1,200 $\mathrm{m}$ and rocky forest at 1,200-1,300 m). Altogether 36 species became known from the area. The comparison of collections revealed that submontane rainforests (including rocky forests) are the richest of the studied forest types in foliicolous lichens. Mt Kanga is characterised by rare species like Calopadia editae discovered by Antonín Vězda in material from Mt Kanga, described and validated in 2011 by Chaves and Lücking based on materials from Mt Kanga and Costa Rica. The palaeotropical Opegrapha viridistellata Sérus., Lücking et Sparrius described in 2008 is reported here as new for Tanzania.
\end{abstract}

Key words: catchment forest, lichenised fungi, Nguru Mts, on leaves

\section{INTRODUCTION}

The Nguru Mts in Morogoro Region are part of the Eastern Arc of the Precambrian crystalline block mountains of Tanzania, East Africa. These mountains enjoyed favourable climatic conditions since their uplift in the Cretaceous and on the rainy slopes the forest vegetation could persist continuously. The massif is divided in four major groups of mountains. Messumbwa, Mafulumula, Manyagu and Kanga, separated from each other by deep, rocky, valleys, which carry their water to the Wami river on the Mkata Plains. Mt 


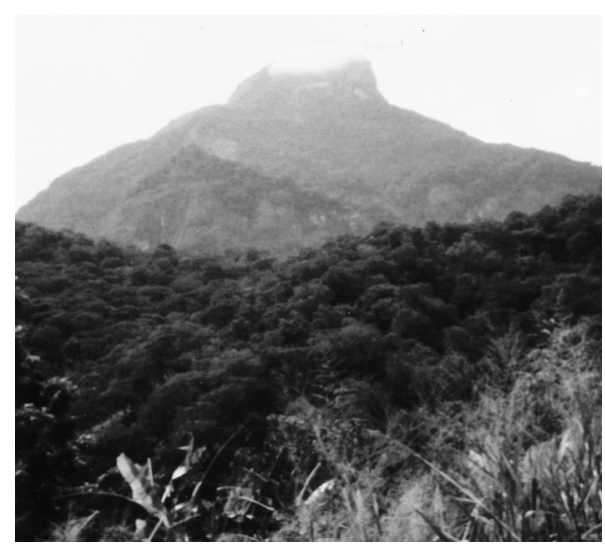

Fig. 1. Mount Kanga, Tanzania, East Africa

Kanga (Fig. 1) consists of three high, very spectacular peaks of 2,019, 1,725 and 1,740 m altitude. The annual rainfall varies between 1,000 and 2,500 mm on Mt Kanga (Pócs et al. 1991). The N-S oriented mountain range is situated between $05^{\circ} 56^{\prime}$ and $06^{\circ} 01^{\prime} \mathrm{S}$, and $37^{\circ} 41^{\prime}$ and $37^{\circ} 44^{\prime} \mathrm{E}$.

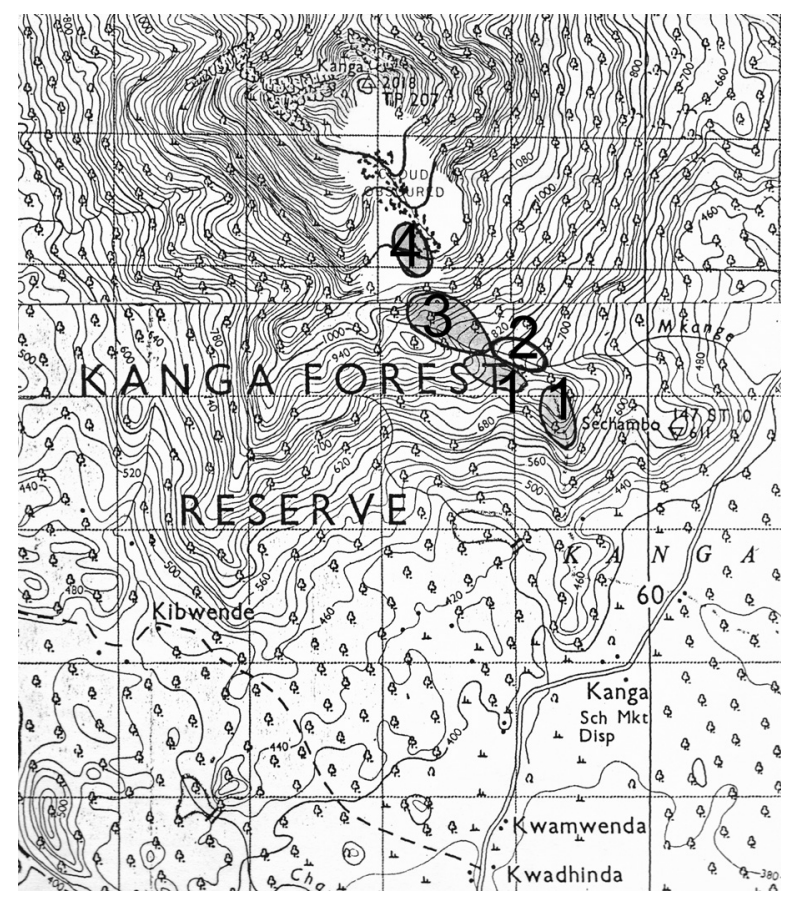

Fig. 2. Localities on Mt Kanga: 1 = (green) dry evergreen and semi-evergreen rainforest, $2=$ (white) lowland rainforest, $3=$ (blue) submontane rainforest, $4=$ (red) rocky forest 
The area of the entire Southern Nguru Mts block is 1,700 km², $340 \mathrm{~km}^{2}$ of which is forested area (Burgess et al. 2007). Kanga Forest Reserve covers $66.64 \mathrm{~km}^{2}$ and its elevation range is between ca 380 and 2,020 m (Doggart and Loserian 2007). The main forest types are: lowland forests from 500 to $800 \mathrm{~m}$ elevation with canopy of $25 \mathrm{~m}$ (emergents to $35 \mathrm{~m}$ ), submontane forest from 750 to 1,300 m with canopy of 30-35 m (on rocky ridges between 1,000 to 1,300 $\mathrm{m}$ on east and south an evergreen rocky forest occurs), montane forests from 1,300 to 2,000 $\mathrm{m}$, where on the summit the forest trees are covered in moss and canopy is 5-10 m tall (Lovett and Pócs 1993).

Foliicolous lichens of various Tanzanian regions have been studied (Farkas 1987, 1991a, b, Farkas and Vězda 1987, 1993, Vězda and Farkas 1988). Mt Kanga remained lichenologically unexplored for a long time, due mainly to its difficult accessibility. The first lichen floristical results are based on the collections of Tamás Pócs and the author (Farkas 1990). The Tanzanian Mt Kanga was at first visited by Tamás Pócs in 1987 when he collected foliicolous lichens in lowland rainforest between 800 and $900 \mathrm{~m}$ elevation and in submontane rainforest between 900 and 1,250 m. Later, in 1989 he returned there with participants of the Nguru Mts expedition, when the author collected further lichens including foliicolous ones in three different forest types (dry evergreen and semi-evergreen forest at $600-800 \mathrm{~m}$, submontane rainforest at 850-1,200 $\mathrm{m}$ and rocky forest at 1,200-1,300 $\mathrm{m}$ ) (Fig. 2).

Of the 322 vascular plant species of Southern Nguru Mts 5 are endemic. The Kanga Forest Reserve has also its species described from its characteristic habitats. The giant Lobelia morogoroensis Knox and Pócs (Fig. 3A) grows on steep rocky sites of Uluguru, Nguru (including sites of Kanga) and Nguru ya Ndege Mountains (Knox and Pócs 1992). A lichen covering mossy bark surfaces, Herpothallon hypoprotocetraricum G. Thor (Fig. 3B) (Aptroot et al. 2009), earlier identified as Cryptothecia rubrocincta (Ehrenb.) Thor (Thor 1991: 282)
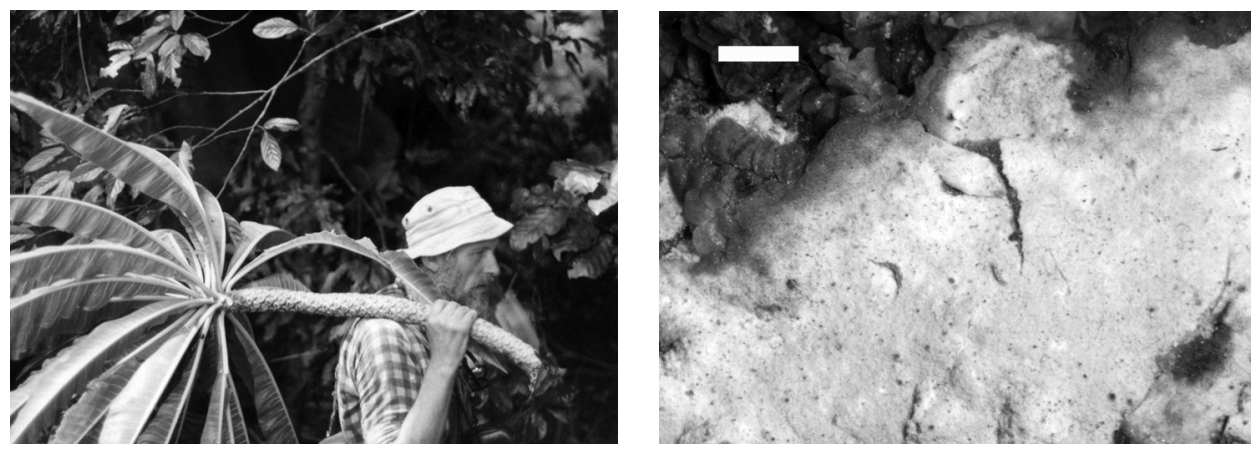

Fig. 3. The giant vascular plant Lobelia morogoroensis carried by Tamás Pócs (A); and the lichen species Herpothallon hypoprotocetraricum (B), which were described from Mt Kanga (scale: $\mathrm{B}=1 \mathrm{~mm}$ ) 
was collected by the present author in rocky forest of Mt Kanga and distributed in Lichenes Delicati Exsiccati Editae (Farkas 2014). The foliicolous lichen species, Calopadia editae Vězda ex Chaves et Lücking (Fig. 4) was discovered by Antonín Vězda in the 1990s in materials from Mt Kanga, its description became possible only after his death, when Chaves and Lücking validated it (Lumbsch et al. 2011: 27) based on material from Mt Kanga and Costa Rica, indicating that it possibly grows also in the Galapagos Islands.
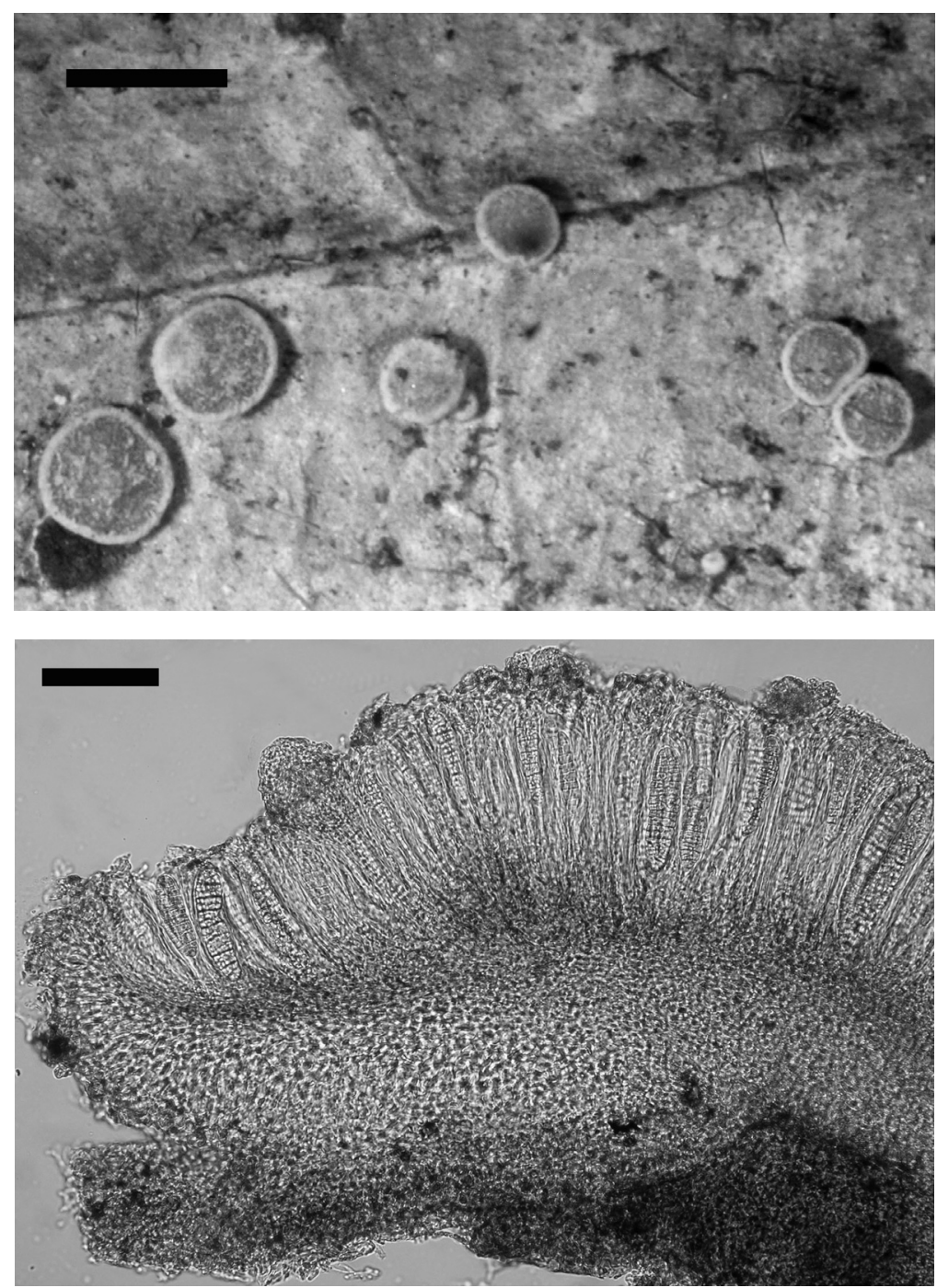

Fig. 4. Calopadia editae Vězda ex Chaves et Lücking has its type locality on Mt Kanga. A= thallus with apothecia; $B=$ section of apothecium (scale: $A=1 \mathrm{~mm}, \mathrm{~B}=50 \mu \mathrm{m}$ ) 


\section{MATERIALS AND METHODS}

The following microscopes were used for identifications: Olympus SZX9 and Olympus BX50 (DIC) microscopes. Recent control investigations, measurements were carried out by a NIKON Eclipse/NiU (DIC, epifluorescence) compound microscope. Micrographs were prepared mostly by Olympus E450 camera (with Quick Photo Camera 2.3 software) and occasionally by Nikon DS-Fi1c camera (with NIS-Elements BR software).

The following sites were visited, indicated by locality numbers, listed in sequence of increasing elevations.

89114 - Dry evergreen and semi-evergreen forest on the lower rocky southeastern slopes of Mt Kanga at 600-800 m, coll. E. Farkas, 31 March 1989. 87226 - Lowland rainforest on the southeastern slope of Mt Kanga, along Mkange stream at 800-900 m, coll. T. Pócs, 2 and 3 December 1987.

87227 - Submontane forest on the southeastern slopes of Mt Kanga along Mkange stream at 900-1,250 m, coll. T. Pócs, 2 December 1987.

89110 - Submontane forest on the southeastern slopes of Mt Kanga along Mkange stream at 850-1,200 m, coll. E. Farkas, 30 March 1989.

89112 - Rocky forest on the southeastern slopes of Mt Kanga at 1,2001,300 m, coll. E. Farkas, 30 March 1989.

Jaccard-index $(\mathrm{K})$ was calculated for comparison of forest types. Lichen specimens are deposited in VBI.

\section{RESULTS AND DISCUSSION}

The species and their localities of Mt Kanga are presented in Table 1. For the nomenclature the following works were considered: Lücking et al. 2000, Lücking and Martínez Colín 2004 and Lücking 2008. Altogether 36 species are listed. From these 7 were collected in dry evergreen and semi-evergreen forest, 11 in lowland forest. Submontane forests (including rocky forests) are the richest concerning to the number of foliicolous lichens with 34 species: 23 species were found in submontane forests and 24 in rocky forest. 13 species are found both in submontane and rocky forests, 10 only in submontane and 10 only in rocky forest $(\mathrm{K}=55 \%)$. Except for Gyalectidium caucasicum (Elenk. et Woron.) Vězda there is no overlap of species of the lower elevation forests: lowland rainforest and dry evergreen and semi-evergreen forests $(\mathrm{K}=$ 17\%). Badimia cateilea (Vain.) Lücking, Lumbsch et Elix occurred exclusively in lowland rainforest. The composition of foliicolous lichens characterises their habitats also in Mt Kanga (cf. Lücking 1997). 


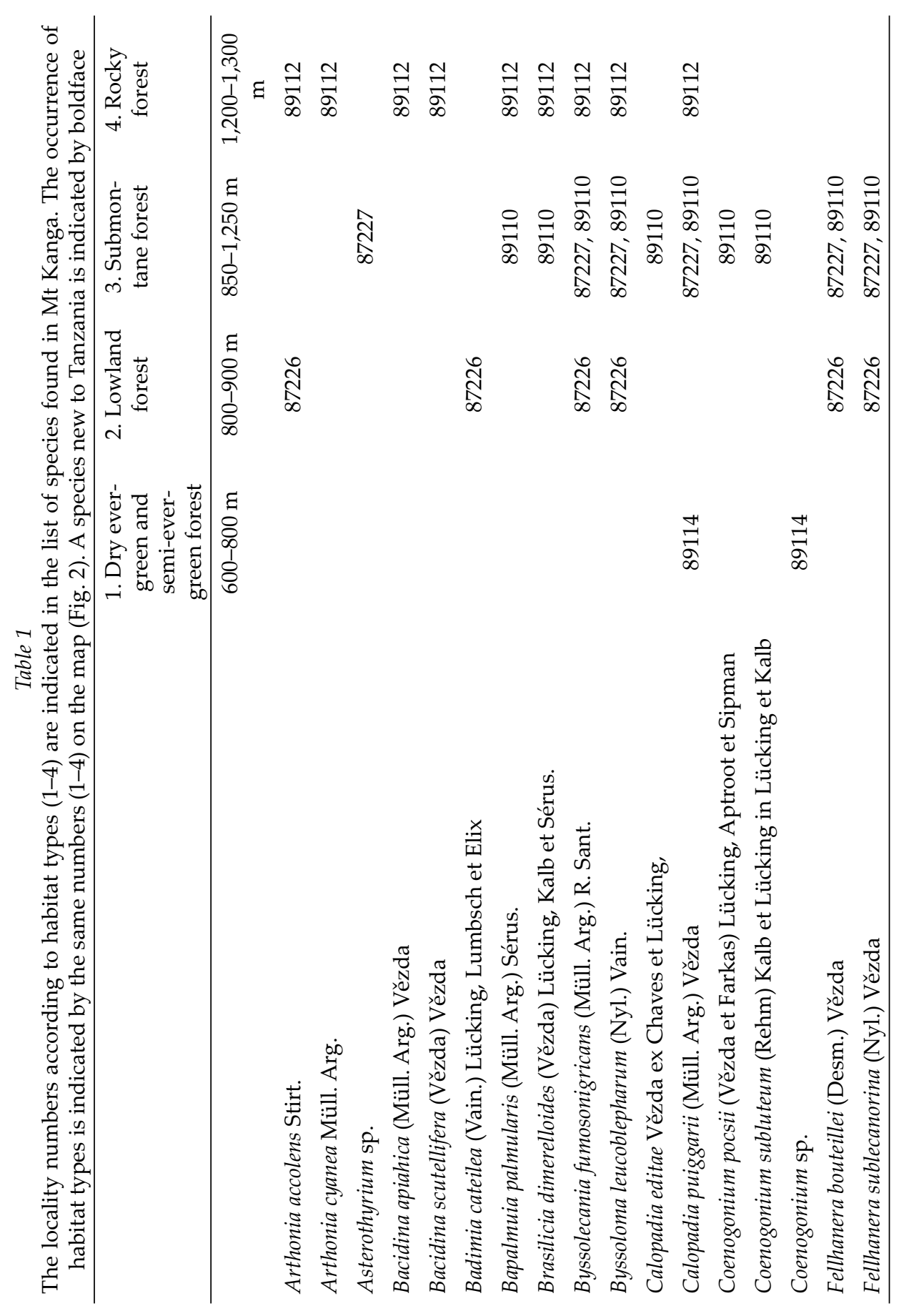

Acta Bot. Hung. 57, 2015 


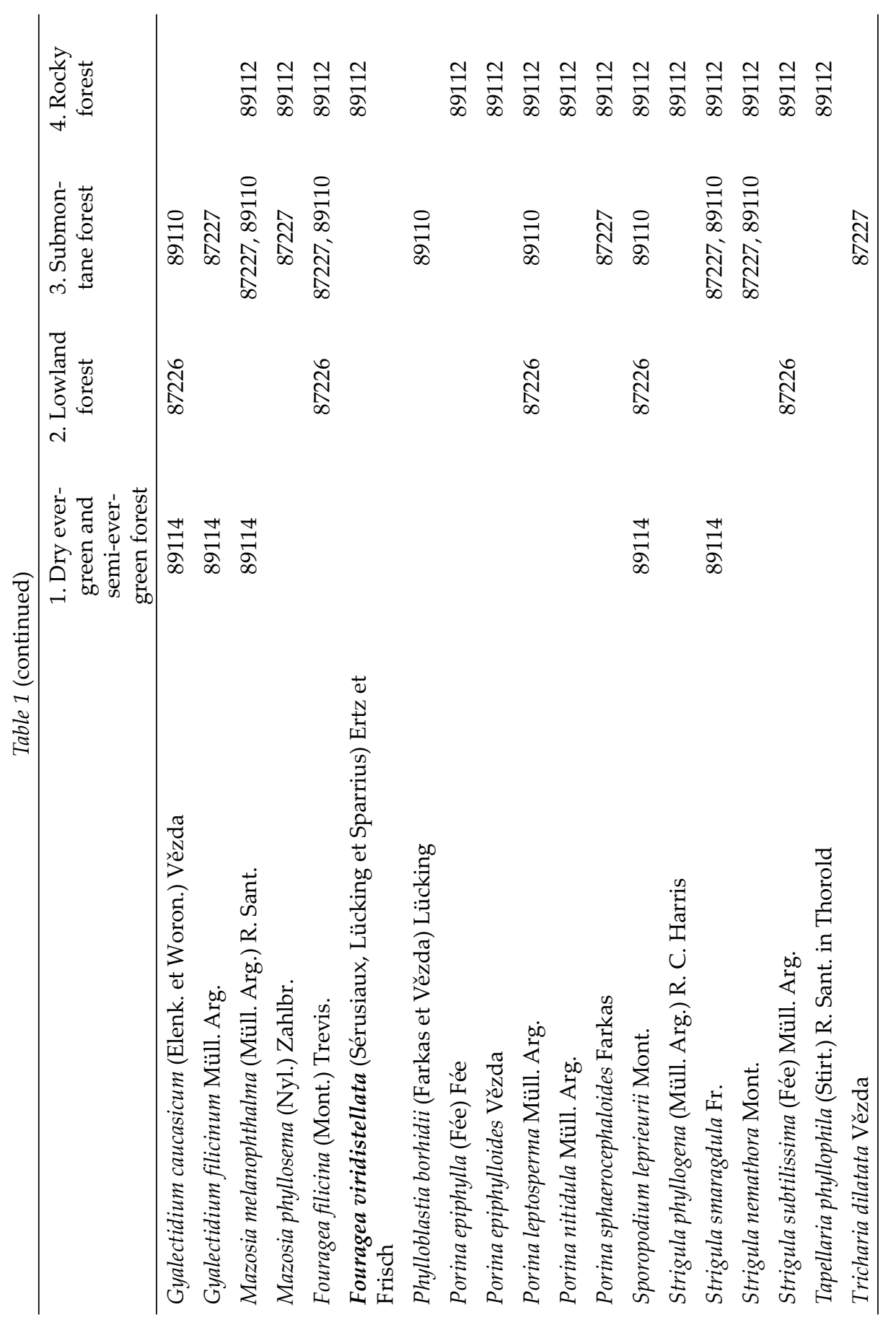

Acta Bot. Hung. 57, 2015 
Brasilicia dimerelloides (Vězda) Farkas, comb. nova

Basionym: Bacidia dimerelloides Vězda, Acta Mus. Silesiae, Opava, ser. A, 23: 179, 1974.

The new combination was originally suggested in a mansucript of Lücking and Martínez Colín (2004). As I agree with the taxonomic decision, the combination is validated here in agreement with the first author.

\section{Fouragea viridistellata (Sérusiaux, Lücking et Sparrius) Ertz et Frisch, Taxon 63(4): 738, 2014.}

Basionym: Opegrapha viridistellata Sérus., Lücking et Sparrius, Mycotaxon 104: 223, 2008.

The species, Opegrapha viridistellata Sérus., Lücking et Sparrius (Sérusiaux et al. 2008) was identified as new from Mt Kanga. Recently it was recombined in a new genus as Fouragea viridistellata (Sérus., Lücking et Sparrius) Ertz et Frisch (Frisch et al. 2014). It was known from Australia, Ivory Coast, Japan, New Caledonia, Papua New Guinea, Seychelles and Thailand. Here it is new for Tanzania from submontane rainforests of mountains Kanga and Uluguru from two different host plants: Pandanus sp. and Marattia sp. Tanzanian specimens are illustrated (Fig. 5).

Specimens investigated: Tanzania. Morogoro Region, in rocky forest on the southeastern slopes of Mt Kanga at 1,200-1,300 m, on leaf of Pandanus sp., coll. E. Farkas 89112/V, 30 March 1989 (VBI 06064). - Tanzania. Morogoro Region, in submontane rainforest in the NNE valley of Lupnaga peak of Northern Uluguru Mts at 1,200-1,400 m, on fronds of Marattia sp., coll. T. Pócs and E. Knox 88192/VI, 28 March 1988 (VBI 06065).
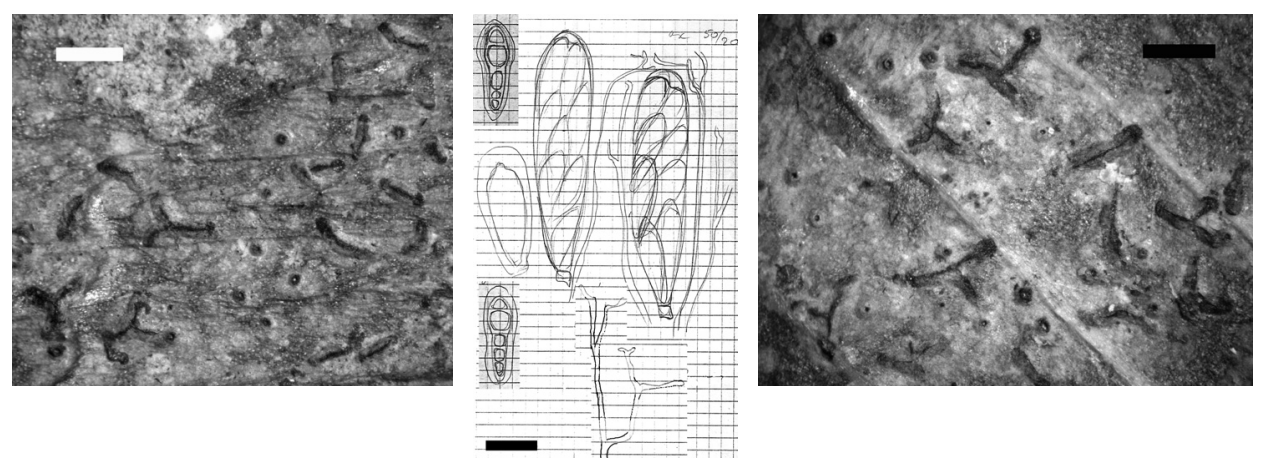

Fig. 5. Fouragea viridistellata (Sérus., Lücking et Sparrius) Ertz et Frisch. Thallus with ascomata and pycnidia (A = Mt Kanga, on Pandanus leaf, $\mathrm{C}=$ Southern Uluguru Mts, on Marattia frond); and a sketchy drawing of details of asci, paraphyses and ascospores from 1990

(B) (scale: A, C = 500 $\mu \mathrm{m}, \mathrm{B}=10 \mu \mathrm{m}$ ) 
Acknowledgements - The author is grateful to the international project for the Conservation of Catchment Forests in Tanzania sponsored by the Hungarian Academy of Sciences, the Royal Swedish Academy of Science and the Sokoine Agricultural University, Dar es Salaam and Morogoro made my field work possible in 1989 in the Southern Nguru Mountains and for Tamás Pócs for the collections and encouragement on this scientific field. Robert Lücking (Chicago, USA) is thanked for advice on nomenclatural questions. The present work was supported by a project of the Hungarian Scientific Research Fund (OTKA K81232).

\section{REFERENCES}

Aptroot, A., Thor, G., Lücking, R., Elix, J. A. and Chaves, J. L. (2009): The lichen genus Herpothallon reinstated. - Biblioth. Lichenol. 99: 19-66.

Burgess, N. D., Butynski, T. M., Cordeiro, N. J., Doggart, N., Fjeldså, J., Howell, K. M., Kilahama, F., Loader, S. P., Lovett, J. C., Mbilinyi, B., Menegon, M., Moyer, D. C., Nashanda, E., Perkin, A., Rovero, F., Stanley, W. T. and Stuart, S. N. (2007): The biological importance of the Eastern Arc Mountains of Tanzania and Kenya. - Biol. Conserv. 134: 209 -231. http://dx.doi.org/10.1016/j.biocon.2006.08.015

Doggart, N. and Loserian, D. (eds) (2007): South Nguru Mountains: a description of the biophysical landscape. - TFCG Technical Paper No 11. DSM Tz, 71 pp.

Farkas, E. (1987): Foliicolous lichens of the Usambara Mountains, Tanzania I. - Lichenologist 19(1): 43-59. http://dx.doi.org/10.1017/S0024282987000057

Farkas, E. (1990): Foliicolous lichens of Mt. Kanga, Tanzania. - In: Reisinger, A. and Bresinsky, A. (eds): Abstracts, IMC4, Regensburg, 28 August-3 September, 1990, p. 18.

Farkas E. (1991a): New and interesting records of Tanzanian foliicolous lichens. - In: Galloway, D. J. (ed.): Tropical lichens: their systematics, conservation, and ecology. Systematics Association Special Volume 43. Clarendon Press, Oxford, pp. 95-104.

Farkas, E. (1991b): The foliicolous lichen flora and vegetation of the Usambara mountains. - In: Hedberg, I. and Persson, E. (eds): Research for conservation of Tanzanian catchment forests. Proceedings from a workshop held in Morogoro, Tanzania, March 13-17, 1989. Uppsala University Press, Uppsala, pp. 86-94.

Farkas, E. (2014): Notes and schedae to Lichenes Delicati Exsiccati Editae in memoriam Antonín Vězda (1920-2008), fasc. 3. - Acta Bot. Hung. 56(1-2): 69-76.

Farkas, E. and Vězda, A. (1987): Macentina borhidii, eine neue foliicole Flechte aus Tansania. - Acta Bot. Hung. 33(3-4): 295-300.

Farkas, E. and Vězda, A. (1993): Five new foliicolous lichen species. - Folia Geobot. Phytotax. 28: 321-330. http://dx.doi.org/10.1007/BF02853518

Frisch, A., Thor, G., Ertz, D. and Grube, M. (2014): The Arthonialean challenge: restructuring Arthoniaceae. - Taxon 63(4): 727-744. http://dx.doi.org/10.12705/634.20

Knox, E. and Pócs, T. (1992): Lobelia morogoroensis: another Tanzanian giant. - Kew Bulletin 47(3): 503-508.

Lovett, J. C. and Pócs, T. (1993): Assessment of the condition of the catchment forest reserves, a botanical appraisal. - Catchment Forest Project. Ministry of Tourism, Natural Resources and the Environment, Dar es Salaam, 300 pp.

Lumbsch, H. T., Ahti, T., Altermann, S., De Paz, G. A., Aptroot, A., Arup, U., Pena, A. B., Bawingan, P. A., Benatti, M. N., Betancourt, L. et al. (2011): One hundred new species of lichenized fungi: a signature of undiscovered global diversity. - Phytotaxa 18: 1-127. 
Lücking, R. (1997): The use of foliicolous lichens as bioindicators. - Abstracta Botanica 21: 99-116.

Lücking, R. (2008): Foliicolous lichenized fungi. - Flora Neotrop. Monogr. 103: 1-867.

Lücking, R. and Martínez Colín, P. (2004): Rapid lichen guides: foliicolous lichens of the world. - The Field Museum, Chicago, mscr.

Lücking, R., Farkas, E., Sérusiaux, E. and Sipman, H. J. M. (2000): Checklist of foliicolous lichens and their lichenicolous fungi. Part I. Foliicolous lichens. - http://www.bio.unibayreuth.de/planta2/ass/robert/lichens/checkfol.html

Pócs, T., Temu, R. A. P. C. and Minja, T. R. A. (1991): Survey of the natural vegetation and flora of the Nguru Mountains. - In: Hedberg, I. and Persson, E. (eds): Research for conservation of Tanzanian catchment forests. Proceedings from a workshop held in Morogoro, Tanzania, March 13-17, 1989. Uppsala University Press, Uppsala, pp. 135-149.

Sérusiaux, E., Lücking, R. and Sparrius, L. B. (2008): Opegrapha viridistellata (Roccellaceae), a new foliicolous lichen species from the Paleotropics. - Mycotaxon 104: 223-227.

Thor, G. (1991): The placement of Chiodecton sanguineum (syn. Chiodecton rubrocinctum), and Cryptothecia striata sp. nov. - Bryologist 94(3): 278-283.

Vězda, A. (1974): Foliicole Flechten aus der Republik Guinea (W-Afrika). II. - Acta Mus. Silesiae 23:173-190.

Vězda, A. and Farkas, E. (1988): Neue foliicole Arten der Flechtengattung Dimerella Trevisan (Gyalectaceae) aus Tansania. - Folia Geobot. Phytotax. 23: 187-197. 